\title{
Hematological and Physiological Effects of Ketamine with and without Xylazine in Dogs
}

\author{
Gebremedhin Yohannes* \\ College of Veterinary Medicine, Hawassa University, Ethiopia
}

Submission: August 13, 2018; Published: August 30, 2018

*Corresponding author: Gebremedhin Yohannes, College of Veterinary Medicine, Hawassa University, P0 Box 5, Hawassa, Ethiopia; Tel: +251-914800882; Email: gebyo2005@gmail.com

\begin{abstract}
An experimental study was conducted to evaluate the effects of ketamine alone and with xylazine combination on anesthetic parameters; on physiological and hematological parameters so as to choose a suitable general anesthetic combination for use in surgical procedures in local breed of dogs in Mekelle, Ethiopia. The experimental study was carried out on ten local breed of dogs and were randomly divided in to two groups with five dogs in each group. Data was collected for analyzing physiological effects of anesthetic combinations; anesthetic effects and hematological effects using physical recording and laboratory analysis. The results of this study showed duration of general anesthesia was $(91 \pm 6.28 \mathrm{~min})$ and animal recovered $(101.2 \pm 6.5 \mathrm{~min})$ and was longer in xylazine-ketamine combination, whereas duration of general anesthesia was $(30 \pm 1.05 \mathrm{~min})$ was shorter in ketamine alone. The result also showed that the physiological and hematological parameters remained significantly unchanged during the anesthesia in both groups. Therefore, relation duration of action, xylazine and ketamine combination was a suitable choice for undertaking of surgical operations in dogs of local breed for longer duration of action i.e. ( $91 \pm 6.28 \mathrm{~min})$ whereas ketamine alone was a suitable choice for shorter duration of action i.e. $(30 \pm 1.05 \mathrm{~min})$ but increases significantly the heart rate. Further studies on several other anesthetic combinations i.e. (acepromazine + xylazine + ketamine and acepromazine + diazepam + ketamine) on local breed of dogs and several other anesthetic combinations may be conducted.
\end{abstract}

Keywords: General anesthesia; Hematological parameter; ketamine; Local breed of dogs; Mekelle; Xylazine

Abbreviations: ANOVA: Analysis of Variance; CSA: Central Statistical Agency; DLC: Differential Leukocyte Counts; EDTA: Ethylene Diamine Tetra Acetic Acid; GABAA: Gamma-Amino Butyric Acid Type A Receptors; Hbc: Hemoglobin Concentration; IM: Intramuscular; Kg: Kilogram; Mg: Milligram; PCV: Packed Cell Volume; SD: Standard Deviation; SPSS: Statistical Package for Social Sciences; TEC: Total Erythrocyte Count; TLC: Total Leukocyte Count; XK: Xylazine - Ketamine

\section{Introduction}

Ketamine hydrochloride is a dissociative anesthetic of the cyclohexylamine group used for chemical restraint and for the induction and maintenance of anesthesia in a number of species. Unlike many anesthetics, ketamine usually stimulates cardiovascular function in normal animals, causing increase in heart rate (HR) and mean arterial pressure (MAP). The use of ketamine as a sole anesthetic has been limited by muscle hypertonicity and myoclonus, violent recovery and occasional occurrence of convulsions [1]. Ketamine is combined with an alpha-2-agonist (e.g. xylazine), a benzodiazepine (e.g. diazepam) or a phenothiazine tranquillizer (e.g. acepromazine) to enhance muscle relaxation, analgesia, to prevent seizures/convulsions and prolong the duration of anesthetic effect. It is associated with a rapid onset, good to excellent sedation of one to two hours duration, excellent analgesia and smooth recovery. The analgesia and sedation are due to central nervous system depression and the muscle relaxation is due to the central inhibition of intraneural transmission [2].
Ketamine is poor in visceral analgesia. However, it can be used in combination with xylazine or diazepam to provide good visceral analgesia in case of abdominal surgery (including ovariohysterectomy) and thoracic surgery. Pain is an unpleasant sensory or emotional experience most commonly associated with potential tissue damage. The sensation of pain is a consequence of the activation of specialized receptors and neurological pathways after such pain stimuli $[3,4]$. Xylazine, an alpha-2 agonist used in animal experiments, stimulates alpha- 2 adrenergic receptor in cerebral presynaptic nerve ends, inhibits release of catecholamines and dopamine resulting in analgesic and sedative eff ects, and hinders nerve conduction in the central nervous system leading to relaxation of striated muscles. Xylazine is usually used in combination with ketamine during anesthetic applications [5].

The combination of ketamine hydrochloride and xylazine $\mathrm{HCl}$ usually result in a smooth induction and recovery with cataleptic effects of ketamine $\mathrm{HCl}$ get ameliorated by the sedative and 
myorelaxing effects of xylazine $\mathrm{HCl}$. [6,7]. Studies on acute pain in clinical cases have most often evaluated the effects of surgical trauma on animals, while prevention and pain management are the key issues in anesthesia [8,9]. When pain is not appropriately managed, it is not only an animal welfare issue, but it can also have many detrimental effects which can impact the patient recovery [10]. A variety of physiological changes also occur in response to pain such as increases in heart rate, respiratory rate, blood pressure and body temperature $[9,11,12]$. Ketamine is rarely used alone because of its association with poor muscle relaxation, tachycardia and catalepsy or muscle rigidity. Therefore, it is commonly used in combination with xylazine, diazepam and acepromazine to minimize the adverse effects. Moreover, there are different breed of dogs which require proper anesthetic medicament combination. However, there are limited or no experiments carried out to determine a specific anesthetic combination in relation to the local breed of dogs in the study area. Hence, determining the effects of the ketamine in combination with other sedative agents may help to come out with the safest combination for surgical procedures in local breed of dogs. Therefore, the purpose of this study is to evaluate the hematological and physiological effects of ketamine with and without xylazine, for use in surgical procedures in local breed of dogs in Mekelle, Ethiopia.

\section{Materials and Methods}

\section{Study area}

The present study was conducted from November 2016 to April 2017 in Mekelle, Tigray, Ethiopia. Mekelle is the capital of Tigray region located about 783 kilometers north of Addis Ababa with a total area of approximately 102,000 square kilo meters. Its geographic location is $13^{\circ} 32^{`} \mathrm{~N}$ latitude and $39^{\circ} 33^{`} \mathrm{E}$ longitude with human population of about 215,546 . It has an average altitude of 2200 meter above sea level with a mean minimum and maximum monthly temperature of 8.7 degree Celsius and 26.8 degree Celsius respectively. The annual average rainfall of Mekelle is 600 millimeters and more than 70 percent of it falls between the months July and August. The long dry season extends from October to May [13].

\section{Study population}

The present study was carried out on mature and apparently healthy local breed of dogs weighing between $10-15 \mathrm{~kg}$ and aged between 2-4 years. Dogs were declared healthy based on physiologically normal parameters i.e. rectal temperature, heart rate, respiratory rate, and capillary refill time.

\section{Sample size}

The present study was carried out on ten mature and apparently healthy local breed of dogs (six males and four females).

\section{Sampling technique}

Ten dogs were randomly divided in to two groups, an experimental group with five dogs (three males and two females) in each group and one control group with five dogs (three males and two females) in each group.

\section{Experimental design and procedure}

Ten (10) local breed of dogs were purchased, of which five dogs were randomly assigned to an induction regimen of ketamine alone (control group) and the other five dogs were assigned to ketamine with xylazine (experimental group). The dogs were housed individually in a kennel, fed meat and bread. Prior to anesthesia, each dog was withheld of food and water for 12 and 6 hours respectively. These dogs were placed in a quiet kennel and left undisturbed. Heart rate, respiratory rate and temperature were recorded prior to premedication. Blood samples were taken prior to premedication. All dogs were premedicated with atropine sulphate at $0.04 \mathrm{mg} / \mathrm{kg}$ body weight subcutaneously for the reduction of salivary and bronchial secretions fifteen minutes before induction of anesthesia with ketamine alone and with xylazine.

\section{Administration of Drugs}

\section{Group 1-control group (ketamine alone)}

First all dogs were premedicated with atropine sulphate at $0.04 \mathrm{mg} / \mathrm{kg}$ body weight subcutaneously. After fifteen minutes of premedication, a combination of xylazine and ketamine were administered at two different doses of ketamine at $5 \mathrm{mg} / \mathrm{kg}$ and $10 \mathrm{mg} / \mathrm{kg}$ IM with one-week interval between trials.

\section{Group 2- experimental group (ketamine with xylazine)}

First all dogs were premedicated with atropine sulphate at $0.04 \mathrm{mg} / \mathrm{kg}$ body weight subcutaneously. After fifteen minutes of premedication, a combination of xylazine and ketamine at two different doses diazepam and ketamine at $1 \mathrm{mg} / \mathrm{kg}$ and $5 \mathrm{mg} / \mathrm{kg}$ respectively and again at $2 \mathrm{mg} / \mathrm{kg}$ and $10 \mathrm{mg} / \mathrm{kg}$ intramuscularly respectively with one week interval between trials.

\section{Monitoring of post intervention}

After administration of the ketamine alone and with xylazine, dogs of all groups were kept under close observation. Induction period, duration of anesthesia and recovery period were recorded. Rectal temperature, respiratory rate, and heart rate were recorded every 5 minutes interval after administration of the anesthetic combinations.

\section{Hematological and physiological parameters}

Three ml of blood sample were collected from cephalic vein of each experimental dog prior to administration of the premedication (atropine sulphate) and 30-45 minutes after administration of the anesthetic agents; because maximum effects occurred at 30-45 minutes. Immediately after collection, the blood samples were transferred in a sterile test tube containing Ethylene Diamine Tetra acetic acid (EDTA) as anticoagulant for estimation of Packed Cell Volume, White blood cells, Hemoglobin concentration, red blood cells and differential leukocyte counts according to the procedures of [14]. Physiological parameters like heart rate, respiratory rate 
and rectal temperature were measured every five minutes after administration of the anesthetic combinations.

\section{Data collection}

Data were collected on physiological effects (heart rate, respiratory rate and rectal temperature), anesthetic effects (induction period, duration of anesthesia, recovery period,) and hematological effects (packed cell volume, red blood cells, white blood cells, hemoglobin concentration and differential leukocyte counts.

\section{Data analysis}

The recorded data was entered into Microsoft excel sheet and analyzed to Mean \pm SD (Standard Deviation) using Statistical Package for Social Sciences (SPSS) version 17.0. Paired t-test was used to compare physiological and hematological parameters taken before and during the administration of the drug combination for each group. One-Way Analysis of Variance (ANOVA) at 95\% confidence interval (CI) was used to determine the level of significant difference in mean values among three groups; to compare the means of induction time, duration of anesthesia and recovery time between the groups. Values of $\mathrm{p} \leq 0.05$ were considered as statistically significant and Values of p $>0.05$ was considered as non-significant.

\section{Results}

\section{Anesthetic effects of ketamine alone and ketamine with xylazine}

In this study, the duration of action ketamine alone at a respective dose of $5 \mathrm{mg} / \mathrm{kg}$ and $10 \mathrm{mg} / \mathrm{kg}$ body weight given intramuscularly were $30 \pm 1.05$ minutes, $25 \pm 1.05$ minutes, respectively, whereas in ketamine with xylazine, the duration of action was $68 \pm 6.28,91 \pm 6.28$ minutes at lower and higher doses respectively (Table 1). So, in this study, the duration of anesthesia was longer in ketamine with xylazine combination as compared with ketamine alone.

Table 1: Effects of ketamine alone (control group), xylazine with ketamine (experimental group) on onset of action, duration and recovery time.

\begin{tabular}{|c|c|c|c|c|}
\hline $\begin{array}{c}\text { Anesthetic } \\
\text { Agents }\end{array}$ & $\begin{array}{c}\text { Doses (Mg/ } \\
\text { Kg) }\end{array}$ & $\begin{array}{c}\text { Onset of } \\
\text { Action } \\
\text { (Min) }\end{array}$ & $\begin{array}{c}\text { Duration } \\
\text { of Action } \\
\text { (Min) }\end{array}$ & $\begin{array}{c}\text { Recovery } \\
\text { Time (Min) }\end{array}$ \\
\hline \multirow{2}{*}{$\begin{array}{c}\text { Control } \\
\text { group }\end{array}$} & $5 \mathrm{mg} / \mathrm{kg}$ & $1.5 \pm 0.5$ & $30 \pm 1.05$ & $120 \pm 7.25$ \\
\cline { 2 - 5 } & $10 \mathrm{mg} / \mathrm{kg}$ & $1 \pm 0.4$ & $25 \pm 1.05$ & $180 \pm 7.25$ \\
\hline \multirow{2}{*}{$\begin{array}{c}\text { Experimental } \\
\text { group }\end{array}$} & $\begin{array}{c}1 \mathrm{mg} / \mathrm{kg} \text { and } \\
5 \mathrm{mg} / \mathrm{kg}\end{array}$ & $8 \pm 2.12$ & $68 \pm 6.28$ & $78.2 \pm 6.53$ \\
\cline { 2 - 5 } & $\begin{array}{c}2 \mathrm{mg} / \mathrm{kg} \text { and } \\
10 \mathrm{mg} / \mathrm{kg}\end{array}$ & $6 \pm 2.12$ & $91 \pm 6.28$ & $101.2 \pm 6.53$ \\
\hline
\end{tabular}

\section{Body Reflexes Activity}

\section{Rightening reflex}

In the current study, the different body reflexes activities were assessed during the anesthesia for the sake of assessing the depth of anesthesia. The rightening reflex was elicited by squeezing or pinching a digit of fore limb and observed whether the dog flexes the leg or withdraws the digit from the investigator during the examination after administration of the anesthetic combinations. In ketamine with xylazine the rightening reflex was lost at $8 \pm 2.12$ minutes in xylazine-ketamne at dose rate of $1 \mathrm{mg} / \mathrm{kg}$ and $5 \mathrm{mg} / \mathrm{kg}$, respectively, $6 \pm 2.12$ minutes in xylazineketamne at $2 \mathrm{mg} / \mathrm{kg}$ and $10 \mathrm{mg} / \mathrm{kg}$, respectively (Table 2). In this study, the rightening reflex remained unchanged throughout the anesthesia in both groups.

Table 2: Loss of body reflexes activity.

\begin{tabular}{|c|c|c|c|c|c|}
\hline \multirow{2}{*}{ Anesthetic Agents } & Doses (Mg/Kg) & Rightening Reflex & Palpebral Reflex & Corneal Reflex & Pedal Reflex \\
\hline \multirow{2}{*}{ Control group } & $5 \mathrm{mg} / \mathrm{kg}$ & $1.5 \pm 0.5$ & $1.6 \pm 0.4$ & $1.6 \pm 0.4$ & $1.7 \pm 0.6$ \\
\cline { 2 - 7 } & $10 \mathrm{mg} / \mathrm{kg}$ & $1 \pm 0.5$ & $1.1 \pm 0.4$ & $1.1 \pm 0.4$ & $1.5 \pm 0.6$ \\
\hline \multirow{2}{*}{ Experimental group } & $1 \mathrm{mg} / \mathrm{kg}$ and $5 \mathrm{mg} / \mathrm{kg}$ & $8 \pm 2.12$ & $8.1 \pm 2.02$ & $8.1 \pm 2.02$ & $8.6 \pm 2.42$ \\
\cline { 2 - 7 } & $2 \mathrm{mg} / \mathrm{kg}$ and $10 \mathrm{mg} / \mathrm{kg}$ & $6 \pm 2.12$ & $6.1 \pm 2.02$ & $6.1 \pm 2.02$ & $6.6 \pm 2.42$ \\
\hline
\end{tabular}

\section{Palpebral reflex}

The palpebral reflex was tested by lightly taping the lateral canthus or medial canthus of the eye and observed whether the dog blinks in response after administration of the anesthetic combinations. In ketamine with xylazine the palpebral reflex was lost at $8.1 \pm 2.12$ minutes in xylazine-ketamne at $1 \mathrm{mg} / \mathrm{kg}$ and $5 \mathrm{mg} / \mathrm{kg}$, respectively, $6.1 \pm 2.12$ minutes in xylazine-ketamne at $2 \mathrm{mg} / \mathrm{kg}$ and $10 \mathrm{mg} / \mathrm{kg}$, respectively (Table 2 ). In this study, the palpebral reflex remained unchanged throughout the anesthesia in both groups.

\section{Corneal reflex, eye position and pupil size}

Corneal reflex was tested by touching the cornea with a drop of sterile water and noted whether the dog blinks in response and withdraws the eye into the orbital fossa. In this observation, the time for corneal reflex loss was the same as to the time loss for palpebral reflex in both groups. In ketamine with zylazine the corneal reflex was lost at $8.1 \pm 2.12$ minutes in xylazine-ketamne administered at dose rate of $1 \mathrm{mg} / \mathrm{kg}$ and $5 \mathrm{mg} / \mathrm{kg}$, respectively, $6.1 \pm 2.12$ minutes in xylazine-ketamne at $2 \mathrm{mg} / \mathrm{kg}$ and $10 \mathrm{mg} / \mathrm{kg}$, respectively (Table 2) In both groups the eyes remained opened, with a central and dilated pupil during the anesthesia. In this study, the corneal reflex remained unchanged throughout the anesthesia in both groups.

\section{Pedal reflex}

The pedal reflex was elicited by squeezing or pinching a digit of hind limb and observed whether the dog flexes the leg or 
withdraws the digit from the investigator during the examination after administration of the anesthetic combinations. In group 1 the pedal reflex was lost at $8.6 \pm 2.12$ minutes in xylazineketamne at $1 \mathrm{mg} / \mathrm{kg}$ and $5 \mathrm{mg} / \mathrm{kg}$, respectively, $6.6 \pm 2.12$ minutes in xylazine-ketamne at $2 \mathrm{mg} / \mathrm{kg}$ and $10 \mathrm{mg} / \mathrm{kg}$, respectively (Table 2). In this study, the pedal reflex remained unchanged throughout the anesthesia in both groups.

\section{Physiological Effects of Ketamine alone and ketamine with xylazine}

Heart rate, respiratory rate and rectal temperature were recorded every 5 minutes after administration of the anesthetic combination of xylazine and ketamine up to the time of recovery. The recorded heart rate, respiratory rate and rectal temperature at 60 minutes after administration of xylazine and ketamine were the same as to the recorded values before administration of the xylazine and ketamine so not analyzed; only those values recorded up to 60 minutes were analyzed. In this study, the heart rate was decreased non- significantly ( $\mathrm{P}=$ 0.061 ) from 30 minutes up to 45 minutes after administration of the combination of xylazine - ketamine (Table 3). The recorded respiratory rate was decreased non- significantly $(\mathrm{P}=0.065)$ from 10 minutes up to 45 minutes following administration of the combination of xylazine - ketamine (Table 3). The recorded rectal temperature was also decreased non- significantly $(\mathrm{P}=$ 0.063 ) from 20 minutes up to 45 minutes after administration of the combination of xylazine - ketamine on both doses (Table 3).

Table 3: Effects of ketamine alone on heart rate $(H R)$, respiratory rate $(R R)$ and rectal temperature $(R T)$ of the control group.

\begin{tabular}{|c|c|c|c|c|c|c|c|c|c|c|c|c|c|}
\hline \multirow{2}{*}{ Parameters } & \multicolumn{13}{|c|}{ Time Interval in Minutes } \\
\hline & BA & 5 & 10 & 15 & 20 & 25 & 30 & 35 & 40 & 45 & 50 & 55 & 60 \\
\hline $\begin{array}{l}\text { HR (beat/ } \\
\text { min) }\end{array}$ & $80.1 \pm 2.2$ & $85.8 \pm 2.23$ & $90.5 \pm 2.24$ & $123.3 \pm 2.34$ & $128.2 \pm 2.26$ & $132 \pm 2.28$ & $137 \pm 2.34$ & $140 \pm 2.35$ & $98.5 \pm 2.41$ & $90.3 \pm 2.47$ & $81.3 \pm 2.35$ & $81.4 \pm 2.24$ & $80.8 \pm 2.23$ \\
\hline $\begin{array}{c}\text { RR (breath/ } \\
\text { min) }\end{array}$ & $23.7 \pm 0.7$ & $23.1 \pm 0.78$ & $18.6 \pm 0.8$ & $17.4 \pm 0.91$ & $17.4 \pm 0.92$ & $16.6 \pm 1.13$ & $15.7 \pm 1.24$ & $15.4 \pm 1.36$ & $15.0 \pm 1.34$ & $20.2 \pm 0.77$ & $23.2 \pm 0.77$ & $23.2 \pm 0.64$ & $23.5 \pm 0.53$ \\
\hline $\operatorname{RT}(0 \mathrm{c})$ & $37.8 \pm 0.77$ & $37.76 \pm 0.79$ & $37.68 \pm 0.80$ & $37.64 \pm 0.85$ & $37.45 \pm 0.87$ & $37.42 \pm 0.89$ & $37.4 \pm 0.912$ & $37.35 \pm 0.93$ & $37.29 \pm 0.95$ & $37.182 \pm 1.02$ & $37.68 \pm 0.84$ & $37.69 \pm 0.79$ & $37.78 \pm 0.69$ \\
\hline
\end{tabular}

\section{Ketamine alone and ketamine with xylazine}

In the current study, blood samples were taken before and during administration of ketamine alone (Table 4) and the anesthetic combinations of xylazine-ketamine for evaluating of hemoglobin concentration, packed cell volume, total erythrocyte count, total leukocyte count, neutrophils, lymphocytes, monocytes, eosinophils and basophils. In group 1 hemoglobin concentration $(\mathrm{P}=0.066)$, packed cell volume $(\mathrm{P}=0.073)$, total erythrocyte count $(\mathrm{P}=0.069)$, total leukocyte count $(\mathrm{P}=0.079)$, lymphocyte $(\mathrm{P}=0.064)$, monocyte $(\mathrm{P}=0.061)$, eosinophil $(\mathrm{P}=0.074)$ and basophils $(\mathrm{P}=0.084)$ were decreased non-significantly, Neutrophils $(\mathrm{P}=1.000)$ were increased nonsignificantly from $58.8 \pm 0.39$ to $64 \pm 0.68$ (Table 5).

Table 4: Effects of Xylazine and Ketamine combination on heart rate (HR), respiratory rate (RR) and rectal temperature (RT) of experimental dogs.

\begin{tabular}{|c|c|c|c|c|c|c|c|c|c|c|c|c|c|}
\hline \multirow{2}{*}{ Parameters } & \multicolumn{13}{|c|}{ Time Interval in Minutes } \\
\hline & BA & 5 & 10 & 15 & 20 & 25 & 30 & 35 & 40 & 45 & 50 & 55 & 60 \\
\hline $\begin{array}{c}\text { HR (beat/ } \\
\text { min) }\end{array}$ & $80.1 \pm 2.2$ & $79.8 \pm 2.23$ & $79.5 \pm 2.24$ & $79.3 \pm 2.34$ & $78.2 \pm 2.26$ & $77.4 \pm 2.28$ & $74.2 \pm 2.34$ & $73.4 \pm 2.35$ & $72.5 \pm 2.41$ & $72.3 \pm 2.47$ & $79.3 \pm 2.35$ & $79.5 \pm 2.24$ & $79.8 \pm 2.23$ \\
\hline $\begin{array}{l}\text { RR (breath/ } \\
\text { min) }\end{array}$ & $23.7 \pm 0.7$ & $23.1 \pm 0.78$ & $18.6 \pm 0.8$ & $17.4 \pm 0.91$ & $17.4 \pm 0.92$ & $16.6 \pm 1.13$ & $15.7 \pm 1.24$ & $15.4 \pm 1.36$ & $15.0 \pm 1.34$ & $20.2 \pm 0.77$ & $23.2 \pm 0.77$ & $23.2 \pm 0.64$ & $23.5 \pm 0.53$ \\
\hline $\mathrm{RT}(0 \mathrm{c})$ & $37.8 \pm 0.77$ & $37.76 \pm 0.79$ & $37.68 \pm 0.80$ & $37.64 \pm 0.85$ & $37.45 \pm 0.87$ & $37.42 \pm 0.89$ & $37.4 \pm 0.912$ & $37.35 \pm 0.93$ & $37.29 \pm 0.95$ & $37.182 \pm 1.02$ & $37.68 \pm 0.84$ & $37.69 \pm 0.79$ & $37.78 \pm 0.69$ \\
\hline
\end{tabular}

Table 5: Effects of ketamine alone (control group), xylazine with ketamine (experimental group) on hematological parameters.

\begin{tabular}{|c|c|c|c|c|c|c|c|c|c|c|}
\hline Anesthetics & & HBC & PCV & TEC & TLC & NTP & LYM & MN & EOS & BAS \\
\hline \multirow{2}{*}{$\begin{array}{l}\text { Control } \\
\text { group }\end{array}$} & $\begin{array}{c}\text { Before } \\
\text { anesthesia }\end{array}$ & $14.3 \pm 0.25$ & $42.3 \pm 0.25$ & $6.4 \pm 0.25$ & $10.3 \pm 0.25$ & $58.9 \pm 0.39$ & $29.9 \pm 0.53$ & $7.4 \pm 0.25$ & $3.5 \pm 0.27$ & $0.9 \pm 0.13$ \\
\hline & $\begin{array}{c}\text { During } \\
\text { anesthesia }\end{array}$ & $13.91 \pm 0.29$ & $41.72 \pm 0.29$ & $5.78 \pm 0.25$ & $9.29 \pm 0.33$ & $65 \pm 0.68$ & $28.1 \pm 0.67$ & $6.5 \pm 0.16$ & $2.6 \pm 0.16$ & $0.5 \pm 0.1632$ \\
\hline \multirow{2}{*}{$\begin{array}{l}\text { Experimental } \\
\text { group }\end{array}$} & $\begin{array}{c}\text { Before } \\
\text { anesthesia }\end{array}$ & $14.2 \pm 0.25$ & $42.2 \pm 0.25$ & $6.2 \pm 0.25$ & $10.2 \pm 0.25$ & $58.8 \pm 0.39$ & $29.8 \pm 0.53$ & $7.2 \pm 0.25$ & $3.4 \pm 0.27$ & $0.8 \pm 0.13$ \\
\hline & $\begin{array}{c}\text { During } \\
\text { anesthesia }\end{array}$ & $13.81 \pm 0.29$ & $41.62 \pm 0.29$ & $5.68 \pm 0.25$ & $9.19 \pm 0.33$ & $64 \pm 0.68$ & $27.1 \pm 0.67$ & $6.4 \pm 0.16$ & $2.5 \pm 0.16$ & $0.4 \pm 0.1632$ \\
\hline
\end{tabular}

$\mathrm{HBC}=$ Hemoglobin concentration, $\mathrm{PCV}=$ Packed cell volume, $\mathrm{TEC}=$ Total erythrocyte count, $\mathrm{TLC}=$ Total

leukocyte count, NTP = Neutrophil, LYM = Lymphocyte, MN = Monocyte, EOS = Eosinophil, BAS = Basophil 
In group 2 hemoglobin concentration $(\mathrm{P}=0.062)$, packed cell volume $(P=0.065)$, total erythrocyte count $(P=0.067)$, total leukocyte count $(\mathrm{P}=0.078)$, lymphocyte $(\mathrm{P}=0.084)$, monocyte $(\mathrm{P}=0.071)$, eosinophil $(\mathrm{P}=0.0614)$ and basophils $(\mathrm{P}=0.083)$ were decreased non-significantly, on the other hand, neutrophils $(\mathrm{P}=1.0211)$ were increased non-significantly from $58.8 \pm 0.39$ to $66.5 \pm 0.34$ (Table 5).

\section{Discussion}

Ketamine is rarely used alone because of its association with poor muscle relaxation, tachycardia and catalepsy or muscle rigidity and it is therefore commonly used in combination with xylazine, diazepam and acepromazine to minimize the untoward effects. The highest duration of anesthesia was observed in the dogs of Group 2 (experimental group) as compared to group 1 (control group). This might be due to wide-distribution of xylazine and ketamine combination in the body, because they are highly soluble in lipid and can be redistributed into muscles and adipose tissues [15]. The results obtained here were relatively in line with the findings of [16] who found 8.3 minutes onset of action after administration of xylazine at dose rate of $1 \mathrm{mg} / \mathrm{kg}$ and ketamine at dose rate of $10 \mathrm{mg} / \mathrm{kg}$ body weight intramuscularly and [17] who reported 96 minutes duration of action after administration of xylazine at dose rate of $1 \mathrm{mg} / \mathrm{kg}$ and ketamine at dose rate of $5 \mathrm{mg} / \mathrm{kg}$ body weight intramuscularly.

In this study, the onset of action of xylazine and ketamine combination was relatively 6 minutes rapid when compared to the studies by [18] who found 12 minutes after administration of xylazine at dose rate of $1 \mathrm{mg} / \mathrm{kg}$ and ketamine at dose rate of $15 \mathrm{mg} / \mathrm{kg}$ body weight intramuscularly. The duration of action of xylazine and ketamine combination was relatively 35.75 minutes longer when compared to the studies by Sindak et al. [16] reported 55.25 minutes. The duration of action of xylazine and ketamine combination was relatively 19.4 minutes longer when compared to the studies by Emami et al. [18] found $71.60 \pm 3.07$ minutes. The recovery time of xylazine and ketamine combination in the present finding was relatively 27.85 minutes longer when compared to the study by Sindak et al. [16] reported 73.15 minutes. This finding difference in the present study from previous studies might be due to difference in breed and physiological status of the dogs or might be due to difference in dose of the anesthetic agents.

In this study, heart rate was increased significantly at 15-35 minutes after administration of ketamine alone but decreased non- significantly at 30-45 minutes, respiratory rate was decreased non-significantly at 10-45 minutes and rectal temperature was decreased non- significantly at 20-45 minutes after administration of xylazine and ketamine combination. The decrease in heart rate, respiratory rate and rectal temperature in this study were in agreement with the studies by Sindak et al. [16] reported decreased heart rate at 30- 45 minutes after administration of xylazine and ketamine combination, decrease in respiratory rate and decrease in rectal temperature at 20-
45 minutes after administration of xylazine and ketamine; Mwangi et al. [19] reported decreased rectal temperature at 30 minutes and Emami et al. [18] reported decreased respiratory rate at 5-55 minutes following administration of xylazine and ketamine combination. On the other hand, Afshar et al. [20] reported significant decrease in heart rate at 15-60 minutes after administration of xylazine and ketamine combination; Kul et al. [21] reported significant decreased in respiratory rate at 15-60 minutes after administration of xylazine and ketamine combination; Demirkan et al. [22] reported significantly remained lower respiratory rate than the baseline throughout the xylazine and ketamine anesthesia and rectal temperature remained significantly decreased at 30-60 minutes after administration of xylazine and ketamine combination.

The decreases in rectal temperature after administration of xylazine and ketamine combination found in the present study were in contrary with the findings of Wyatt et al. [23] reported unchanged in rectal temperature after administration of xylazine at $1 \mathrm{mg} / \mathrm{kg}$ and ketamine at $10 \mathrm{mg} / \mathrm{kg}$ body weight intramuscularly in dogs. The decrease in body temperature after the administration of ketamine alone and xylazineketamine, could be explained by blocking of the hypothalamic thermoregulatory center. The decrease in heart rate could be attributed to inhibition of the release of the neurotransmitter noradrenalin or depression of the sympathetic activity.

The decrease in respiratory rate could be attributed to depression of the respiratory center by the ketamine alone, xylazine-ketamine, [24]. The non-significant decrease in heart rate, respiratory rate and rectal temperature in the present study when compared to other studies might be due to difference in breed and physiological status of the dogs or might be due to difference in dose of the sedative agents. After administration of ketamine alone, and xylazine - ketamine combinations, the hemoglobin concentration, packed cell volume, total erythrocyte count, total leukocyte count, lymphocyte, monocyte, eosinophil and basophils were decreased non-significantly, but neutrophils were increased non-significantly. Pooling of circulating blood cells in the spleen and other reservoirs secondary to decreased sympathetic activity could be the reason for a decrease in hemoglobin concentration, packed cell volume, total erythrocyte count, total leukocyte count, lymphocyte, monocyte, eosinophil and basophils [25]. The decrease in hemoglobin concentration, packed cell volume, total erythrocyte count, total leukocyte count, lymphocyte, monocyte, eosinophil and basophils after administration of ketamine alone, xylazine and ketamine combination might be attributed to the shifting of fluid from extravascular compartment to intravascular compartment in order to maintain normal cardiac output in the dogs [26].

This finding is in agreement with the findings of Mahmud et al. [27] who had reported decreased the hemoglobin concentration, packed cell volume, total erythrocyte count, total leukocyte count, lymphocyte, monocyte, eosinophil and 
basophils and increased neutrophils after administration of xylazine at $0.4 \mathrm{mg} / \mathrm{kg}$ and ketamine at $10 \mathrm{mg} / \mathrm{kg}$ combination in dogs. In the current study, heart rate was decreased nonsignificantly at 30-45 minutes, respiratory rate decreased nonsignificantly at 10-45 minutes after administration of ketamine alone, the xylazine-ketamine, intramuscularly and rectal temperature decreased non-significantly at 20-45 minutes after administration of ketamine alone, and xylazine-ketamine, combinations intramuscularly [28-30].

\section{Conclusion}

Ketamine is rarely used alone because of its association with poor muscle relaxation, visceral analgesia, tachycardia and catalepsy or muscle rigidity. Therefore, it is commonly used in combination with xylazine, diazepam and acepromazine to enhance muscle relaxation, to provide good visceral analgesia in case of abdominal surgery (including ovariohysterectomy) and thoracic surgery, to prevent seizures/convulsions and to prolong the duration of anesthetic effect. The study was conducted on 10 mature and apparently healthy local breed of dogs which were randomly grouped in to Group I and Group II. All dogs were premedicated using atropine $(0.04 \mathrm{mg} / \mathrm{kg}$ BW, S.C). After 15 mints premedication, anesthesia induced with ketamine a lone, and xylazine-ketamine $(1.0 \mathrm{mg} / \mathrm{kg} / \mathrm{BW}+10.0 \mathrm{mg} / \mathrm{kg} \mathrm{BW}, \mathrm{I.M})$ for Group I, and Group II respectively. The anesthetic parameters; induction time, duration of anesthesia recovery period, the physiological parameters; temperature, heart rate, respiratory rate, and the hematological parameters; packed cell volume, total erythrocyte count, total leukocyte count, hemoglobin determination were recorded and analyzed in all both groups and all the anesthetic parameters were found statistically significant but the physiological and hematological parameters were statistically non-significant in both groups. The results of the present study concluded that xylazine-ketamine combination is useful anesthetic protocol for rapid induction, prolonged duration of anesthesia; diazepam-ketamine combination is useful anesthetic protocol for short duration of anesthesia and rapid recovery. All drug combinations do not affect the physiological and hematological parameters of the animals during the study time and all of them can be safe for surgical procedures if used safely and appropriately. However, further studies on several other anesthetic combinations i.e. (acepromazine + xylazine + ketamine and acepromazine + diazepam + ketamine) on local breed of dogs and several other anesthetic combinations may be conducted.

\section{Acknowledgements}

A special gratitude goes to Mekelle University, without its support; the study would not have been possible. Great thanks go to Dr. H. for all his help in analyzing the research data and Mr. Yisehak, T. the surgery technician for his help and cooperation rendered during the experimental study. I never forget to say thanks to Mr. Kane, W. the pathology laboratory staff worker for his help, patience, permission and full information during my working period.

\section{References}

1. Muir WW, Lerche P, Robertson JT, Hubbell JA, Beard W (2000) Comparison of four drug combinations for total intravenous anesthesia of horses undergoing surgical removal of an abdominal testis. J Am Vet Med Assoc 217: 869-873.

2. Muir W (2008) Cylohexamine drug mixtures: The pharmacology of ketamine and ketamine combination drugs. Proceedings of second International Congress of Veterinary Anesthesia. Veterinary Publishing Co Santa Barbara 4: 5-14.

3. Mathews A (2000) Pain assessment and general approach to management. Veterinary Clinical North America Small Animal Practice 30: 729-755.

4. Junior E, Santos J, Russo C, Elsensaut P, Headley A (2009) Evaluation of cortisol levels of dogs anesthetized with sevoflurane and premedicated with butorphanol 30(2): 425-433.

5. Ozkan F, Cakir N, Eyibilen A, Yener T, Erkorkmaz U (2010) Comparison of ketamine-diazepam with ketamine-xylazine anesthetic combinations in sheep spontaneously breathing and undergoing maxillofacial surgery. Bosmian J Basic Med Sci 10: 297-302.

6. Gulanber E, Baştan A, Tasal I, Aktas M, Arikan N (2001) Ketamine as general anesthesia. Journal of the faculty of veterinary medicine, Istanbul university 27(2): 401-409.

7. Durrani F, Ashraf M, Khan A (2009) A comparisons of the clinical effects associated with xylazine, ketamine and a xylazine-ketamine cocktail in pigeons (Columba Livia). Turk J of Vet Ani Sci 33: 413-417.

8. Tranquilli J, Thurmon C, Grimm A (2007) Lumb and Jones' Veterinary Anesthesia and Analgesia. (4 ${ }^{\text {th }}$ edn,) Wiley-Blackwell, UK, pp. 80-105.

9. Gaynor S, Muir W (2008) Handbook of Veterinary Pain Management. Drugs acting on the central nervous system ( $\left.2^{\text {nd }} e d n\right)$, pp. 78-109.

10. Orskov T (2010) Pain assessment in cats and dogs. Irish Journal of Veterinary science 63(6): 362-364.

11. Atalan H, Gunes V, Cihan M, Celebi F, Citil M (2002) Comparisons of xylazine + ketamine- $\mathrm{HCl}$ an aesthetic agent with acepromazine + butorphanol + ketamine combinations for their clinical, cardiovascular and respiratory effects in dogs 8: 35-40.

12. Bergamasco L, Osella C, Savarino P, Larosa G, Ozella L (2010) Heart rate variability assessment in shelter dog. Application animal Science 125(1): 56-68.

13. CSA (2008) Central Statistical Agency: Report on monthly average retail prices of goods and services. Statistics Bulletn. pp. 416.

14. Orpet H, Welsh P (2002) Handbook of Veterinary Nursing. Implementation a patient care plan. $\left(1^{\mathrm{st}} \mathrm{edn}\right)$, Blackwell Science Ltd., USA 10: 244-251.

15. Azizpour A, Hassani Y (2012) Clinical evaluation of general an aesthesia with a combination of Ketamine HCL and Diazepam in pigeons. Journal of Agriculture 7: 101-105.

16. Sindak N, Camekerten I, Ceylan C (2010) clinical evaluation of xylazineketamine anesthesia in bozova greyhounds. Journal of animal and veterinary advances 9(15): 2025-2029.

17. Naqialbayati T (2015) A comparative study between of effect of tramadol and xylazine as premedication those followed by ketamine anesthesia in dogs. Kufa journal for veterinary medical sciences 6: 2 .

18. Emami R, Sedighi R, Sarhaddi S (2010) Cardiovascular and respiratory effects of romfidine or xylazine in ketamine anesthesia in dogs. Iranian journal of veterinary surgery 36(2): 110-123. 
19. Mwangi E, Mogoa M, Nguhiu J, Mulei M (2014) Effects of epidural Ketamine, Xylazine and their combinations on body temperature in acepromazine-sedated dogs. International Journal of Advanced Research 2: 336-340.

20. Afshar S, Baniadam A, Marashipour P (2005) Effect of xylazine ketamine on arterial blood pressure, arterial blood $\mathrm{pH}$, blood gases, rectal temperature, heart rate and respiratory rate in goat. Bulletin of the Veterinary Institute in Pulawy 49: 481-484.

21. Kul M, Koc Y, Alkand F, Ogurtan Z (2000) The effects of xylazineketamine and diazepam-ketamine on arterial blood pressure and blood gases in dogs. Journal of Veterinary Research 4: 123-132.

22. Demirkan G, Gokce I, Ozaydin D, Celebi F (2002) Comparative study of butorphanol-ketamine and xylazine ketamine combinations for their clinical, cardiovascular and respiratory effects in healthy dogs. Turkey journal of veterinary and animal science 26: 1073-1079.

23. Wyatt D, Scott W, Richardson E (2001) The effects of prolonged ketamine-xylazine intravenous infusion on arterial blood $\mathrm{pH}$, blood gases, mean arterial blood pressure, heart and respiratory rates, recta temperature and reflexes in the dogs. Journal of Veterinary Science 39: 411-415.

24. Walter H (2008) Handbook of Veterinary Pharmacology: Drugs Acting on the Central Nervous System. Wiley-Blackwell, UK, pp. 81-107.
25. Kilic N (2004) Physiological and hematological changes in ketamine and diazepam anesthesia in horse. Indian Journal of Veterinary 81: 396-398.

26. Wagner A, Muir W, Hinchclif K (2001) Cardiovascular effects of xylazine and detomidine in horse. American Journal of Veterinary Research 52: 651-657.

27. Mahmud A, Shaba P, Yisa H, Gana J, Ndagimba R (2014) Comparative efficacy of Diazepam, Ketamine and Diazepam-Ketamine combination for sedation or anesthesia. Journal of advances Veterinary Animal Research 1(3): 107-113.

28. Ferreira P, Dzikiti B, Zeiler E, Buck R, Nevill B (2015) Anesthetic induction and recovery characteristics of a diazepam-ketamine combination compared with propofol in dogs. Journal of the South African Veterinary Association 86(1): 1258.

29. Winer J, Brown R, Michels K (2001) Statistical principles in experimental designs. ( $3^{\text {rd }}$ edn), Mcgraw hill series, USA, p. 1057.

30. Amarpal P, Kinjavdekar P, Aithal A, Pawde K, Singh J (2010) Evaluation of Xylazine, Acepromazine and Medetomidine + Ketamine for general anesthesia in rabbits. Scandinavian Journal of Laboratory Animal Sciences 37: 3.

\section{Your next submission with Juniper Publishers will reach you the below assets}

- Quality Editorial service

- Swift Peer Review

- Reprints availability

- E-prints Service

- Manuscript Podcast for convenient understanding

- Global attainment for your research

- Manuscript accessibility in different formats ( Pdf, E-pub, Full Text, Audio)

- Unceasing customer service

Track the below URL for one-step submission https://juniperpublishers.com/online-submission.php 